\title{
Mechanisms and diversity of resistance to sorghum shoot fly, Atherigona soccata
}

Mohammed Riyazadin ${ }^{1,2}$, Polavarapu B. Kavi Kishor ${ }^{2}$, Are Ashok Kumar ${ }^{1}$, Belum V. S. Reddy Rajendra S. Munghate ${ }^{1}$ and Hari C. Sharma ${ }^{1,3}$

${ }^{1}$ Entomology, International Crops Research Institute for the Semi-Arid Tropics (ICRISAT), Patancheru 502 324, Telangana, India; ${ }^{2}$ Department of Genetics, Osmania University, Hyderabad 500 007, Telangana, India; ${ }^{3}$ Corresponding author, E-mail: h.sharma@cgiar.org With 2 figures and 11 tables

Received November 1, 2014 / Accepted April 20, 2015

Communicated by M. Prasad

\begin{abstract}
Sorghum shoot fly, Atherigona soccata, is one of the important pests of postrainy season sorghums. Of the 90 sorghum genotypes evaluated for resistance to this pest, RHRB 12, ICSV 713, 25026, 93046 and 25027 , IS 33844-5, Giddi Maldandi and RVRT 3 exhibited resistance in postrainy season, while ICSB 463, Phule Anuradha, RHRB 19, Parbhani Moti, ICSV 705, PS 35805, IS 5480, 5622, 17726, 18368 and 34722, RVRT 1, ICSR 93031 and Dagidi Solapur showed resistance in rainy season, suggesting season-specific expression of resistance to A. soccata. ICSB 461, ICSB 463, Phule Yasodha, M 35-1, ICSV 700, 711, 25010, 25019 and 93089, IS 18662, Phule Vasudha, IS 18551 and 33844-5 and Barsizoot had fewer deadhearts than plants with eggs across seasons, suggesting antibiosis as one of the resistance mechanism. Five genotypes exhibited resistance with high grain yield across seasons. Correlation, path and stepwise regression analyses indicated that leaf glossiness, seedling vigour, trichome density, oviposition and leaf sheath pigmentation were associated with the expression of resistance/susceptibility to shoot fly, and these can be used as marker traits to select and develop shoot fly-resistant sorghums.
\end{abstract}

Key words: Sorghum bicolor — postrainy — deadheart resistance — antibiosis — Atherigona soccata

Sorghum, Sorghum bicolor (L.) Moench, is the fifth most important grain crop after maize, rice, wheat and barley. It is a staple food for over 750 million people in Africa, Asia and Latin America (CAC 2011). India is the largest sorghum grower in the world with an area of 6.18 million hectares, production of 5.28 million tons and an average productivity of $854.4 \mathrm{~kg} / \mathrm{ha}$ (FAO 2014). Sorghum is a multipurpose crop for food, feed and fodder, and of late, it is emerging as a fuel crop for bioethanol production. Several biotic and abiotic constraints influence the production and productivity of sorghum. Among the biotic constraints, insect pests are one of the major factors influencing the grain yield in sorghum and result in losses of over $\$ 1000$ million in grain and forage yield (ICRISAT 1992, 2007). Nearly 32\% of the actual production of sorghum is lost because of insect pests in India (Borad and Mittal 1983).

More than 150 insect pests damage sorghum, of these, sorghum shoot fly, Atherigona soccata (Rondani), is one of the major insect pests of sorghum (Sharma 1993). Sorghum shoot fly, infests the sorghum plant from the first to the fourth week after seedling emergence. Under humid conditions, female fly lays elongated cigar-shaped eggs on the abaxial surface of the leaf, parallel to the leaf midrib. After egg hatching, the maggot crawls to the central whorl of the leaves, reaches the growing point, cuts the central leaf and feeds on it. As a result, the central whorl dries off and gives a typical deadheart symptom (Fig. 1). Usually, shoot fly population begins to increase in July, peaks in August-September and declines thereafter. The shoot fly infestations are high when sorghum plantings are staggered due to erratic rainfall (Sharma 1985). Shoot fly infestations are normally high in the postrainy season crops planted from September to October. Temperatures above $35^{\circ} \mathrm{C}$ and below $18^{\circ} \mathrm{C}$, and continuous rainfall or very dry weather reduce shoot fly survival (Jotwani 1978).

Shoot fly infestation leads to heavy crop loss due to decrease in grain and fodder yields. Losses due to shoot fly damage can be reduced by using resistant varieties, following good cultural practices, timely planting and timely application of proper insecticides (Sharma 1985). However, planting times in the semi-arid tropics (SAT) are dependent on the onset of rains, while the cost of insecticides restricts the poor farmers from applying them (Sharma 1993). Therefore, host plant resistance (HPR) is one of the most effective means of keeping shoot fly populations below economic threshold levels. Plant resistance to sorghum shoot fly appears to be a complex character and depends on the interplay of number of componential characters, which finally sum up in the expression of resistance to shoot fly (Dhillon 2004). A number of genotypes with resistance to shoot fly have been identified, but the levels of resistance are low to moderate (Jotwani 1978, Taneja and Leuschner 1985, Sharma et al. 2003). In India, shoot fly has attained the status of a principal pest mainly because of the introduction of improved sorghum varieties and hybrids susceptible to this insect, continuous cropping, ratooning and narrow genetic variability (Singh and Rana 1986). The sorghum cultivars to be grown during the postrainy season must have moderate to high levels of primary or recovery resistance to shoot fly (Sharma 1993). Efforts have been made to transfer shoot fly resistance into cytoplasmic male-sterile and restorer lines to produce shoot fly-resistant hybrids (Dhillon et al. 2005, Sharma et al. 2005, Belum VS Reddy et al. 2006). None of the newly developed varieties or hybrids has been able to replace the landrace cultivar, 'Maldandi' (M 35-1), as they have limited shoot fly resistance. Phule Yasodha, Phule Chitra and ParbhaniMoti, which have moderate levels of resistance to shoot fly, have been adopted by the farmers in certain areas. However, the level of resistance to shoot fly in the identified sources varies with insect density and across environments (Sharma and Nwanze 1997, Dhillon et al. 2005). Therefore, it is crucial to identify the sorghum genotypes with different resistance mechanisms to increase the levels and diversify the basis of resistance to this insect. Hence, the present studies were undertaken to identify the lines with diverse mechanisms of resistance to shoot fly, with adaptation to the postrainy season, which can be used in breeding to diversify the basis of resistance to shoot fly, A. soccata. 


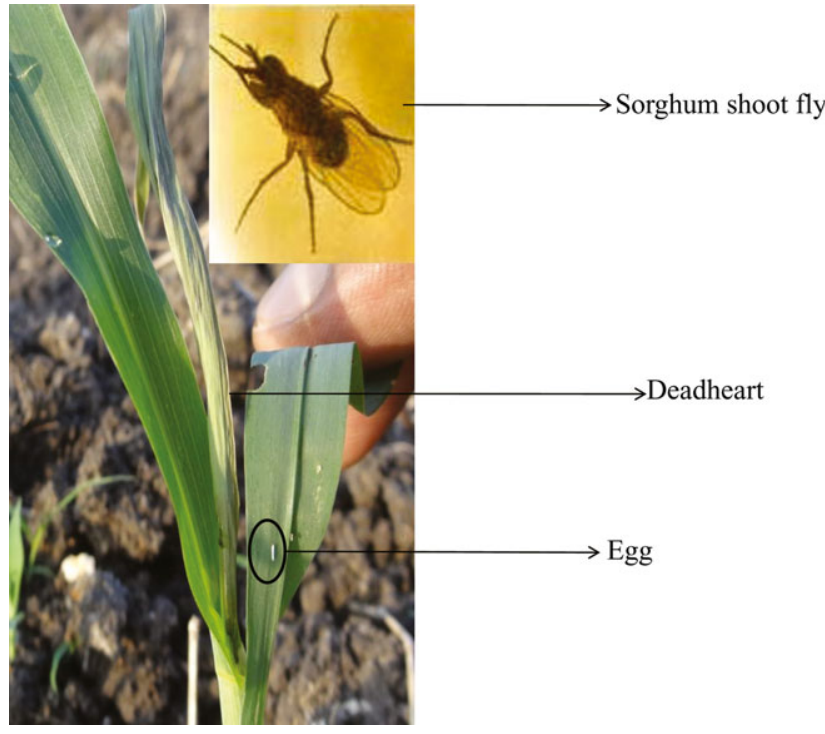

Fig. 1: Shoot fly deadheart bearing an egg under the surface of the leaf Inset: sorghum shoot fly, Atherigona soccata

\section{Materials and Methods}

Experimental material: The experiments were conducted during the 2010 postrainy and 2011 rainy seasons, at the International Crops Research Institute for the Semi-Arid Tropics (ICRISAT), Patancheru, Telangana, India (latitude $17.53^{\circ} \mathrm{N}$, longitude $78.27^{\circ} \mathrm{E}$ and altitude of $545 \mathrm{~m})$.

The test material consisted of a diverse array of 90 sorghum genotypes comprising of germplasm accessions, landraces, breeding lines and commercial cultivars with adaptation to postrainy season in India. Postrainy season sorghums are typically grown under receding moisture on deep to shallow black soils (Vertisols) between September and February. A basal dose of fertiliser (Ammonium phosphate@100 kg/ha) was applied for raising the crop. The test genotypes were sown in two rows of $2.0 \mathrm{~m}$ length, with a row-to-row spacing of $75 \mathrm{~cm}$ and a spacing of $10 \mathrm{~cm}$ between the plants within a row. There were two replications in a randomized complete block design (RCBD). The seeds were sown with a two-cone planter at a depth of $5.0 \mathrm{~cm}$ below the soil surface. Thinning was carried out for 7 days after seedling emergence (DAE) and before the onset of shoot fly incidence, and 35-40 plants were retained in each plot. Interlard fish-meal technique was used to increase the shoot fly incidence in the test material (Soto 1974, Sharma et al. 1992). Interculture was carried out at 15 and 30 DAE; earthing up and application of urea at $100 \mathrm{~kg} / \mathrm{ha}$ were carried out at $30 \mathrm{DAE}$ and the field was irrigated after every 20 days of interval in postrainy season; and hand weeding was carried out whenever necessary, but there was no insecticide application in the experimental block. One set of the test material was also grown under protected conditions to record data on agronomic and morphological traits.

\section{Observations}

Shoot fly damage parameters: Data were recorded on plants with shoot fly eggs and number of shoot fly eggs at 14 DAE and shoot fly deadhearts at $21 \mathrm{DAE}$ and expressed as the percentage of plants with shoot fly eggs and deadhearts and number of eggs per 100 plants. Overall resistance score was recorded on 1-9 scale before harvesting ( $1=$ plants with $<10 \%$ deadhearts and uniform tillers and harvestable panicles; 9 = plants with $>80 \%$ deadhearts, and a few or no productive tillers) (Sharma et al. 1992)

Morphological characteristics: Data were recorded on leaf glossiness, leafsheath pigmentation and seedling vigour at 7-10 DAE and trichome density on the abaxial and adaxial leaf surfaces at 14 DAE. Data were also recorded on waxy bloom, plant colour, inflorescence exsertion, inflorescence compactness, inflorescence shape, glume colour, grain lustre, grain colour, total soluble sugars (TSS), endosperm texture, grain subcoat, glume coverage and endosperm colour (IBPGR and ICRISAT 1993). Leaf glossiness was evaluated visually on a 1-5 scale at 10-12 DAE (fifth leaf stage), when the expression of this trait is most apparent, in the early morning hours, when there was maximum reflection of light from the leaf surface $(1=$ highly glossy and $5=$ non-glossy) (Sharma and Nwanze 1997). The leafsheath pigmentation was visually scored on a 1-3 rating scale at 7 DAE (Dhillon et al. 2006c). Seedling vigour was recorded at 10 DAE on $1-3$ scale $(1=$ highly vigorous and $3=$ poor plant vigour $)$ (Sharma and Nwanze 1997). The density of trichomes on both the surfaces of leaf was recorded at $12 \mathrm{DAE}$ by taking a $2.5-\mathrm{cm}^{2}$ portion from the centre of the fifth leaf (Maiti and Bidinger 1979). The leaf samples were taken from three plants at random and placed in acetic acid and alcohol $(2: 1)$ in stoppered glass vials $(10 \mathrm{ml}$ capacity) for $24 \mathrm{~h}$ to clear the chlorophyll, and subsequently transferred into lactic acid (90\%) as a preservative. The leaf sections were mounted on a glass slide in a drop of lactic acid and observed at $10 \times$ magnification under a stereomicroscope. The trichomes on the abaxial and adaxial leaf surfaces were counted and expressed as numbers of trichomes in a $10 \times$ microscopic field.

Waxy bloom was visually scored on a $1-3$ scale $(1=$ slightly waxy and 3 = completely waxy) at the flag leaf stage of the crop. Plant colour was evaluated visually on a $1-2$ scale $(1=$ pigmented - non-tan, and $2=$ nonpigmented - tan); inflorescence exsertion was scored on a 1-3 scale $(1$ = panicle fully exserted and $3=$ poor panicle exsertion $)$; inflorescence compactness on a $1-3$ scale $(1=$ loose inflorescence and $3=$ compact inflorescence); inflorescence shape on a $1-4$ scale $(1=$ erect inflorescence and 4 = elliptic inflorescence); glume colour on $1-6$ scale $(1=$ white glume and $6=$ purple glume); glume coverage on a $1-9$ scale $(1=25 \%$ grain covered with glumes and $9=$ glumes longer than the grain); leaf midrib colour on a $1-4$ scale $(1=$ white coloured midrib and $4=$ brown coloured midrib); awns as $1=$ absence of awns and $2=$ presence of awns; grain lustre as $1=$ non-lustrous grain and $2=$ lustrous grain; and grain colour on a $1-5$ scale $(1=$ white coloured grain and $5=$ buff coloured grain). Data on endosperm texture were recorded on a $1-5$ scale $(1=\mathrm{com}-$ pletely corneous endosperm and $5=$ completely starchy endosperm); grain subcoat was evaluated on a 1-2 scale $(1=$ absence of subcoat, and 2 = presence of subcoat); and endosperm colour was evaluated on a 1-3 scale $(1=$ white coloured endosperm and $3=$ red coloured endosperm) (IBPGR and ICRISAT 1993). Total soluble sugars (TSS) was recorded with the help of hand refractometer $\left(\mathrm{ATAGO}^{\circledR}\right.$ Master $-\alpha$, Cat. no. 2311,

\begin{tabular}{lrcccc}
\hline & \multicolumn{1}{c}{$\begin{array}{c}\text { Plants } \\
\text { with shoot fly } \\
\text { eggs }(\%)\end{array}$} & $\begin{array}{c}\text { Total number } \\
\text { of shoot fly } \\
\text { eggs/100 plants }\end{array}$ & $\begin{array}{c}\text { Shoot fly } \\
\text { deadhearts (\%) }\end{array}$ & ORS \\
\hline Replication & df & 48.40 & 351.00 & 659.40 & 1.59 \\
Genotype & 89 & $1442.80^{* *}$ & $14921.00^{* *}$ & $1655.90^{* *}$ & $7.37^{* *}$ \\
Season & 1 & $7316.60^{* *}$ & $101144.00^{* *}$ & $6324.50^{* *}$ & $8.08^{* *}$ \\
Genotype*Season & 89 & $285.20^{* *}$ & $4771.00^{* *}$ & $308.80^{* *}$ & $1.82^{* *}$ \\
Error & 178 & 186.50 & 1832.00 & 172.80 & 0.88 \\
Total & 358 & & & & \\
\hline
\end{tabular}

Table 1: Mean sum of squares of analysis of variance and of sorghum genotypes evaluated for resistance to shoot fly, Atherigona soccata (ICRISAT, Patancheru, 2010 postrainy and 2011 rainy seasons)

**Mean sum of squares significant at $\mathrm{P}=0.01$; ORS, overall resistance score. 
Table 2: Evaluation of sorghum genotypes for resistance to sorghum shoot fly, Atherigona soccata, in the postrainy season sorghums (ICRISAT, Patancheru, 2010-2011)

\begin{tabular}{|c|c|c|c|c|c|c|c|c|}
\hline \multirow[b]{2}{*}{ Genotype } & \multicolumn{2}{|c|}{$\begin{array}{l}\text { Number of shoot fly } \\
\text { eggs/100 plants }\end{array}$} & \multicolumn{2}{|c|}{$\begin{array}{c}\text { Plants with shoot fly } \\
\text { eggs }(\%)\end{array}$} & \multicolumn{2}{|c|}{$\begin{array}{l}\text { Plants with shoot fly } \\
\text { deadhearts }(\%)\end{array}$} & \multicolumn{2}{|c|}{ ORS } \\
\hline & 2010PR & 2011R & 2010PR & 2011R & 2010PR & 2011R & 2010PR & 2011R \\
\hline ICSB 433 & 114.0 & 64.0 & 30.3 & 57.5 & 37.5 & 50.0 & 6.5 & 5.5 \\
\hline ICSB 461 & 100.0 & 94.0 & 60.2 & 77.2 & 52.3 & 74.2 & 7.5 & 5.0 \\
\hline ICSB 463 & 65.0 & 66.0 & 47.1 & 58.3 & 40.7 & 51.0 & 5.5 & 4.0 \\
\hline ICSV 700 & 139.0 & 67.0 & 44.6 & 58.3 & 37.6 & 55.6 & 5.5 & 4.5 \\
\hline Phule Yasodha & 82.0 & 61.0 & 53.7 & 56.1 & 34.3 & 38.6 & 5.0 & 4.0 \\
\hline Macia & 189.0 & 117.0 & 57.1 & 78.0 & 61.7 & 77.3 & 7.0 & 6.5 \\
\hline ICSV 745 & 146.0 & 97.0 & 81.5 & 81.6 & 83.3 & 76.6 & 7.0 & 6.5 \\
\hline Mouli & 109.0 & 79.0 & 61.8 & 62.1 & 58.3 & 62.7 & 5.5 & 6.0 \\
\hline Phule Chitra & 66.0 & 48.0 & 48.2 & 45.2 & 50.8 & 49.5 & 4.5 & 4.5 \\
\hline NTJ 2 & 270.0 & 137.0 & 82.5 & 89.2 & 73.3 & 87.5 & 7.5 & 6.0 \\
\hline Phule Anuradha & 54.0 & 32.0 & 46.1 & 32.3 & 59.5 & 27.3 & 5.5 & 3.5 \\
\hline RHRB 12 & 61.0 & 93.0 & 36.4 & 70.7 & 39.8 & 73.6 & 5.5 & 5.0 \\
\hline RHRB 19 & 114.0 & 36.0 & 65.1 & 36.0 & 58.5 & 41.0 & 4.5 & 4.0 \\
\hline M 35-1 & 86.0 & 51.0 & 51.6 & 46.1 & 36.6 & 41.1 & 4.5 & 5.0 \\
\hline Parbhani Moti & 109.0 & 51.0 & 53.3 & 41.3 & 56.9 & 39.8 & 4.0 & 5.0 \\
\hline CSV 18R & 73.0 & 73.0 & 54.0 & 57.9 & 63.6 & 60.6 & 5.0 & 4.5 \\
\hline CSV 15 & 213.0 & 131.0 & 82.5 & 89.5 & 73.2 & 91.6 & 6.0 & 6.0 \\
\hline ICSV 702 & 70.0 & 44.0 & 38.2 & 38.8 & 37.7 & 46.1 & 5.0 & 3.5 \\
\hline ICSV 705 & 98.0 & 56.0 & 53.0 & 51.9 & 48.5 & 42.7 & 6.0 & 3.5 \\
\hline ICSV 707 & 68.0 & 77.0 & 20.0 & 64.2 & 20.1 & 50.7 & 4.5 & 4.5 \\
\hline ICSV 711 & 87.0 & 60.0 & 45.8 & 55.0 & 36.3 & 43.7 & 5.0 & 4.0 \\
\hline ICSV 713 & 92.0 & 66.0 & 41.6 & 62.3 & 41.6 & 59.9 & 5.0 & 4.5 \\
\hline ICSV 714 & 137.0 & 102.0 & 64.7 & 78.7 & 51.0 & 75.6 & 5.5 & 3.5 \\
\hline ICSV 25006 & 36.0 & 43.0 & 48.5 & 23.7 & 43.4 & 45.4 & 4.5 & 5.0 \\
\hline ICSV 25010 & 83.0 & 69.0 & 40.0 & 69.2 & 31.1 & 46.5 & 5.5 & 3.0 \\
\hline ICSV 25019 & 41.0 & 80.0 & 38.1 & 67.7 & 19.4 & 59.3 & 6.5 & 4.0 \\
\hline ICSV 25022 & 40.0 & 37.0 & 39.9 & 33.9 & 34.4 & 41.8 & 4.5 & 3.5 \\
\hline ICSV 25026 & 55.0 & 63.0 & 36.2 & 54.4 & 48.7 & 50.0 & 4.5 & 3.0 \\
\hline ICSV 25027 & 129.0 & 60.0 & 45.6 & 49.0 & 35.9 & 58.5 & 5.0 & 5.5 \\
\hline ICSV 25039 & 82.0 & 39.0 & 18.5 & 34.1 & 31.5 & 43.4 & 5.5 & 3.5 \\
\hline ICSV 93089 & 62.0 & 55.0 & 47.2 & 55.1 & 31.4 & 39.2 & 6.0 & 6.5 \\
\hline IS 5480 & 90.0 & 35.0 & 54.4 & 33.4 & 43.3 & 37.2 & 5.5 & 4.0 \\
\hline PS 35805 & 55.0 & 36.0 & 18.4 & 38.9 & 15.4 & 24.3 & 7.0 & 3.0 \\
\hline IS 1044 & 139.0 & 100.0 & 60.7 & 81.8 & 59.3 & 70.3 & 6.5 & 4.0 \\
\hline IS 1104 & 79.0 & 44.0 & 28.3 & 38.5 & 38.1 & 38.8 & 3.5 & 4.0 \\
\hline IS 2123 & 79.0 & 30.0 & 27.0 & 25.6 & 24.7 & 20.3 & 3.5 & 4.0 \\
\hline IS 2146 & 52.0 & 56.0 & 44.6 & 45.8 & 39.1 & 40.4 & 4.0 & 4.5 \\
\hline IS 2312 & 49.0 & 36.0 & 34.1 & 35.5 & 35.9 & 27.2 & 4.5 & 4.0 \\
\hline IS 4646 & 56.0 & 43.0 & 25.3 & 44.3 & 28.3 & 25.5 & 5.0 & 3.0 \\
\hline IS 5470 & 46.0 & 54.0 & 27.1 & 54.2 & 21.6 & 19.2 & 4.0 & 3.0 \\
\hline IS 5604 & 84.0 & 36.0 & 33.8 & 36.2 & 33.9 & 15.0 & 4.0 & 4.0 \\
\hline IS 5622 & 69.0 & 37.0 & 51.7 & 37.0 & 62.5 & 33.9 & 4.5 & 5.0 \\
\hline IS 17726 & 88.0 & 35.0 & 60.6 & 33.6 & 56.2 & 32.3 & 5.0 & 5.0 \\
\hline IS 18368 & 75.0 & 63.0 & 63.9 & 51.9 & 65.4 & 41.3 & 6.5 & 5.0 \\
\hline IS 18662 & 87.0 & 76.0 & 65.4 & 62.6 & 47.4 & 33.5 & 4.5 & 5.0 \\
\hline Akola Kranti & 66.0 & 38.0 & 35.6 & 37.6 & 28.2 & 32.7 & 4.5 & 4.5 \\
\hline Phule Vasudha & 96.0 & 66.0 & 53.6 & 60.6 & 44.7 & 50.4 & 4.5 & 4.5 \\
\hline ICSV 93046 & 93.0 & 83.0 & 42.5 & 67.5 & 37.5 & 58.3 & 5.5 & 4.0 \\
\hline IS 10023 & 231.0 & 109.0 & 70.0 & 90.7 & 45.8 & 89.3 & 8.0 & 6.0 \\
\hline IS 11189 & 293.0 & 248.0 & 77.0 & 96.0 & 75.5 & 96.0 & 7.0 & 6.5 \\
\hline IS 11200 & 325.0 & 143.0 & 88.6 & 92.7 & 80.5 & 92.9 & 5.5 & 6.0 \\
\hline IS 11469 & 133.0 & 144.0 & 62.0 & 91.4 & 81.4 & 91.4 & 6.0 & 7.5 \\
\hline IS 11510 & 534.0 & 123.0 & 59.2 & 92.5 & 86.3 & 96.7 & 6.0 & 7.5 \\
\hline IS 12195 & 178.0 & 106.0 & 83.3 & 93.1 & 71.8 & 89.1 & 6.0 & 7.0 \\
\hline RVRT 1 & 70.0 & 84.0 & 81.6 & 64.2 & 70.2 & 57.1 & 6.5 & 6.0 \\
\hline IS 38162 & 148.0 & 177.0 & 80.9 & 97.3 & 84.5 & 95.7 & 8.0 & 7.0 \\
\hline IS 23891 & 118.0 & 167.0 & 60.4 & 90.2 & 77.4 & 89.6 & 6.1 & 8.5 \\
\hline IS 23930 & 178.0 & 139.0 & 90.8 & 93.2 & 80.9 & 94.7 & 7.5 & 8.0 \\
\hline IS 23999 & 94.0 & 84.0 & 92.8 & 68.0 & 87.8 & 66.7 & 8.0 & 7.0 \\
\hline IS 27954 & 136.0 & 116.0 & 72.9 & 82.5 & 92.3 & 87.0 & 8.5 & 8.0 \\
\hline IS 28102 & 53.0 & 123.0 & 81.2 & 89.5 & 69.9 & 100.0 & 5.7 & 8.5 \\
\hline IS 28792 & 177.0 & 143.0 & 68.5 & 89.5 & 72.4 & 88.1 & 7.5 & 7.0 \\
\hline IS 31705 & 191.0 & 153.0 & 83.3 & 91.4 & 92.8 & 93.1 & 5.7 & 9.0 \\
\hline IS 41204 & 95.0 & 169.0 & 47.6 & 96.8 & 75.4 & 95.3 & 7.1 & 8.0 \\
\hline IS 41207 & 150.0 & 139.0 & 100.0 & 93.9 & 83.3 & 90.4 & 5.7 & 9.0 \\
\hline IS 34722 & 276.0 & 100.0 & 81.5 & 67.6 & 69.6 & 66.1 & 6.0 & 5.0 \\
\hline
\end{tabular}


Table 2. (continued)

\begin{tabular}{|c|c|c|c|c|c|c|c|c|}
\hline \multirow[b]{2}{*}{ Genotype } & \multicolumn{2}{|c|}{$\begin{array}{l}\text { Number of shoot fly } \\
\text { eggs/100 plants }\end{array}$} & \multicolumn{2}{|c|}{$\begin{array}{c}\text { Plants with shoot fly } \\
\text { eggs }(\%)\end{array}$} & \multicolumn{2}{|c|}{$\begin{array}{l}\text { Plants with shoot fly } \\
\text { deadhearts }(\%)\end{array}$} & \multicolumn{2}{|c|}{ ORS } \\
\hline & 2010PR & 2011R & 2010PR & 2011R & 2010PR & 2011R & 2010PR & $2011 R$ \\
\hline IS 34723 & 225.0 & 156.0 & 83.3 & 95.6 & 87.5 & 89.9 & 6.0 & 7.5 \\
\hline IS 34724 & 109.0 & 165.0 & 68.5 & 90.4 & 78.8 & 88.9 & 6.0 & 7.0 \\
\hline IS 34725 & 140.0 & 150.0 & 69.0 & 93.3 & 62.0 & 89.1 & 8.1 & 6.5 \\
\hline IS 34726 & 194.0 & 174.0 & 94.2 & 94.0 & 78.1 & 91.0 & 6.0 & 6.0 \\
\hline IS 34727 & 454.0 & 175.0 & 71.5 & 92.3 & 78.6 & 89.6 & 5.5 & 5.5 \\
\hline IS 34728 & 258.0 & 140.0 & 67.5 & 84.1 & 62.5 & 82.6 & 7.0 & 7.5 \\
\hline RVRT 2 & 114.0 & 71.0 & 42.9 & 58.3 & 39.6 & 65.5 & 4.5 & 5.0 \\
\hline IS 34730 & 128.0 & 132.0 & 65.1 & 87.7 & 63.8 & 86.2 & 4.5 & 6.0 \\
\hline IS 34731 & 252.0 & 197.0 & 73.8 & 89.5 & 47.9 & 88.1 & 4.5 & 6.5 \\
\hline IS $33844-5$ & 50.0 & 103.0 & 53.8 & 63.4 & 43.5 & 55.9 & 5.5 & 5.5 \\
\hline Giddi Maldandi & 158.0 & 104.0 & 50.8 & 74.7 & 53.4 & 68.3 & 4.5 & 6.5 \\
\hline Barsizoot & 100.0 & 82.0 & 67.2 & 70.8 & 44.8 & 62.5 & 5.5 & 5.0 \\
\hline M 35-1-19 & 118.0 & 149.0 & 59.7 & 93.4 & 37.5 & 93.4 & 4.5 & 8.0 \\
\hline ICSR 93031 & 135.0 & 42.0 & 77.8 & 38.6 & 74.4 & 38.6 & 7.0 & 5.0 \\
\hline ICSB 52 & 157.0 & 180.0 & 77.5 & 94.7 & 67.6 & 94.7 & 8.0 & 9.0 \\
\hline RVRT 3 & 85.0 & 85.0 & 53.6 & 68.4 & 48.6 & 58.9 & 5.0 & 4.0 \\
\hline ICSB 24002 & 301.0 & 182.0 & 71.4 & 96.5 & 62.3 & 96.8 & 6.0 & 9.0 \\
\hline ICSB 38 & 93.0 & 130.0 & 59.5 & 89.8 & 48.6 & 87.3 & 8.0 & 9.0 \\
\hline Dagidi Solapur & 161.0 & 76.0 & 51.0 & 59.6 & 68.5 & 53.4 & 4.5 & 5.5 \\
\hline $296 \mathrm{~B}$ & 125.0 & 113.0 & 72.2 & 81.6 & 79.1 & 83.2 & 7.0 & 6.0 \\
\hline ICSR 92003 & 123.0 & 133.0 & 80.3 & 92.8 & 85.2 & 87.4 & 7.5 & 6.0 \\
\hline DJ 6514 & 76.0 & 196.0 & 77.7 & 98.7 & 66.7 & 100.0 & 5.0 & 6.5 \\
\hline IS $18551(R)$ & 76.0 & 25.0 & 51.0 & 25.0 & 42.2 & 24.7 & 4.5 & 4.5 \\
\hline Swarna $(S)$ & 223.0 & 146.0 & 71.2 & 89.7 & 58.7 & 86.7 & 8.0 & 6.5 \\
\hline Mean & 128.92 & 95.43 & 58.4 & 67.42 & 55.5 & 63.85 & 5.73 & 5.54 \\
\hline $\mathrm{SE} \pm$ & 37.83 & 19.81 & 10.34 & 8.87 & 10.98 & 7.32 & 0.74 & 0.59 \\
\hline $\mathrm{Vr}$ & $5.16^{1}$ & $6.27^{1}$ & $3.37^{1}$ & $6.41^{1}$ & $3.20^{1}$ & $11.14^{1}$ & $2.83^{1}$ & $7.70^{1}$ \\
\hline $\operatorname{LSD}(\mathrm{P}=0.05)$ & 106.34 & 55.66 & 29.04 & 24.93 & 30.86 & 20.57 & 2.08 & 1.66 \\
\hline
\end{tabular}

${ }^{1} F$-test significant at $\mathrm{P}=0.01 ; \mathrm{R}$, rainy season; $\mathrm{PR}$, postrainy season; $(R)$, resistant check; $(S)$, susceptible check; SE, standard error Vr, variance ratio; and ORS, overall resistance score (1 plant with uniform tillers and harvestable panicles, and 9 plants with a few or no productive tillers).

Brix $0.0 \sim 33.0 \%$ ). For this purpose, the plant at physiological maturity stage was cut with secateurs at the centre of the 4 th internode and squeezed to extract the juice. A drop of this juice was placed on to the hand refractometer, and the value of TSS was recorded.

Agronomic characteristics: The data on agronomic traits (days to 50\% flowering, plant height, agronomic score, 100-seed weight and grain yield) were also recorded. The data on days to $50 \%$ flowering were recorded when half the panicle and nearly $50 \%$ of plants in the plot had attained the anthesis stage. Plant height of three plants was taken at maturity, which were selected at random within a plot. Agronomic desirability was recorded at crop maturity on a $1-5$ scale $(1=\operatorname{good}$ productive potential and ability to withstand insect damage; $5=$ poor productive potential and prone to insect damage). Data on 100-seed weight and grain yield were recorded after harvesting.

\section{Statistical analysis}

The data were subjected to analysis of variance (ANOVA) using GenStat ${ }^{\circledR}$ 13th version (GenStat 2010). Significance of the differences between the genotypes was judged by $F$-test, while the genotypic means were compared by least significant difference (LSD) at $\mathrm{P} \leq 0.05$. Simple correlations, stepwise regression and path coefficient analyses were performed using GenStat, SAS 9.2 (SAS Institute Inc. 2004) and GENRES statistical software package (GENRES 1994), respectively, to identify morphological traits associated with the shoot fly resistance and grain yield.

\section{Results}

Expression of resistance to sorghum shoot fly, Atherigona soccata, across seasons

The genotypic and environmental interactions were significant $(\mathrm{P}<0.001)$ for percentage of plants with shoot fly eggs and eggs per 100 plants, plants with shoot fly deadhearts and overall resistance score (Table 1). However, the mean sum of squares for environmental effects was relatively higher than the genotypic effects, suggesting that environment has a considerable bearing on the expression of resistance to A. soccata.

There were significant differences between the genotypes for number of shoot fly eggs per 100 plants, percentage of plants with shoot fly eggs and deadhearts, and overall resistance score in both the seasons (Table 2). The genotypes Phule Yasodha, Phule Chitra, M 35-1, ICSV 702, ICSV 707, ICSV 711, ICSV 25006, ICSV 25010, ICSV 25022, ICSV 25039, IS 1104, IS 2123, IS 2146, IS 2312, IS 4646, IS 5470, IS 5604, Akola Kranti and IS 18551 were not preferred for egg laying and suffered lower deadheart incidence (15-51\% deadhearts) as compared to the susceptible check, Swarna (86\% plants with deadhearts). These genotypes also exhibited better tolerance (recovery resistance) to shoot fly damage (overall resistance score $<4.5$ ). RHRB 12, ICSV 713, ICSV 25026, ICSV 25027, ICSV 93046, IS 33844-5, Giddi Maldandi and RVRT 3 exhibited resistance to shoot fly in the postrainy season, while ICSB 463, Phule Anuradha, RHRB 19, Parbhani Moti, ICSV 705, IS 5480, PS 35805, IS 5622, IS 17726, IS 18368, RVRT 1, IS 34722, ICSR 93031 and Dagidi Solapur showed resistance to shoot fly damage in the rainy season. The genotypes ICSB 461, ICSB 463, ICSV 700, Phule Yasodha, M 35-1, ICSV 711, ICSV 25010, ICSV 25019, ICSV 93089, IS 18662, Phule Vasudha, IS 18551, IS 33844-5 and Barsizoot had less number of plants with shoot fly deadhearts than the number of plants with eggs, suggesting that these genotypes have antibiosis mechanism of resistance to A. soccata. 
The genotypes ICSB 463, ICSV 700, Phule Yasodha, Phule Chitra, CSV 18R, ICSV 707, ICSV 711, ICSV 713, ICSV 25019, ICSV 25039, ICSV 93089, IS 5480, IS 2146, IS 2312, IS 4646, IS 5604, IS 5622, IS 18662, Akola Kranti, Phule Vasudha, RVRT 2, Giddi Maldandi, M 35-1-19, RVRT 3, Dagidi Solapur, IS 33844-5 and IS 18551 were glossy with pigmented leafsheath and high trichome density with plant vigour (Annexure S1). Some of these genotypes exhibited resistance to shoot fly damage across seasons, with a few exceptions.

Association between the parameters measuring the expression of resistance to shoot fly, Atherigona soccata

Number of shoot fly eggs per 100 plants and percentage of plants with shoot fly eggs $(r=0.94 * *$ and $0.59 * *$, respectively, for rainy and postrainy seasons) and deadhearts $\left(r=0.92^{* *}\right.$ and $\left.0.52^{* *}\right)[*, * *$ correlation coefficients significant at $\mathrm{P}=0.05$ and $\mathrm{P}=0.01$, respectively] were correlated significantly and positively (data not shown). The overall resistance/susceptibility score was significantly and positively correlated with eggs per 100 plants $\left(r=0.73^{* *}\right.$ and $0.36^{* *}$, for rainy and postrainy seasons, respectively), plants with eggs $\left(r=0.67^{* *}\right.$ and $\left.0.51^{* *}\right)$ and deadheart incidence $(r=0.73 * *$ and $0.52 * *)$. Plants with shoot fly eggs were also positively correlated with deadheart incidence $\left(r=0.93^{* *}\right.$ and $\left.0.84 * *\right)$.

Association of morphological traits with the expression of resistance to sorghum shoot fly, Atherigona soccata

The correlation coefficients between the agronomic and morphological traits with the expression of resistance to shoot fly, A. soccata, revealed that 100 -seed weight, leafsheath pigmentation, seedling vigour score, leaf glossiness score, waxy bloom, plant colour, grain colour, endosperm texture and endosperm colour were significantly and positively correlated with resistance/susceptibility to shoot fly damage in both the seasons (Table 3). Trichomes on the abaxial and adaxial leaf surfaces, inflorescence exsertion, grain coverage by the glume, grain lustre and awns were negatively and significantly correlated with resistance to shoot fly damage in both the seasons. Agronomic score and plant height showed significant and negative associations with shoot fly-resistant traits during the rainy season, while grain

Table 3: Association of agronomic and morphological traits with the expression of resistance to sorghum shoot fly, Atherigona soccata, in the postrainy season sorghums

\begin{tabular}{|c|c|c|c|c|}
\hline Plant traits & $\begin{array}{c}\text { Number of } \\
\text { shoot fly } \\
\text { eggs/100 plants }\end{array}$ & $\begin{array}{l}\text { Plants with } \\
\text { shoot fly } \\
\text { eggs }(\%)\end{array}$ & $\begin{array}{c}\text { Plants with } \\
\text { shoot fly } \\
\text { deadhearts }(\%)\end{array}$ & ORS \\
\hline \multicolumn{5}{|l|}{ Agronomic traits } \\
\hline $\begin{array}{l}\text { Days to } 50 \% \\
\text { flowering }\end{array}$ & $0.31 * *(-0.08)$ & $0.22 *(-0.05)$ & $0.23 *(0.09)$ & $0.09(-0.09)$ \\
\hline Agronomic score & $-0.30 * *(0.04)$ & $-0.33 * *(0.12)$ & $-0.37 * *(0.12)$ & $-0.20 *(-0.27 * *)$ \\
\hline Plant height & $-0.13(0.03)$ & $-0.17(0.06)$ & $-0.16(0.11)$ & $-0.03(-0.34 * *)$ \\
\hline 100-seed weight & $0.40 * *(0.25 *)$ & $0.39 * *(0.52 * *)$ & $0.40 * *\left(0.45^{* *}\right)$ & $0.41 * *(0.16)$ \\
\hline Grain yield & $0.23 *(-0.42 * *)$ & $0.24 *(-0.63 * *)$ & $0.21 *(-0.60 * *)$ & $0.12(-0.71 * *)$ \\
\hline \multicolumn{5}{|l|}{ Morphological traits } \\
\hline $\begin{array}{l}\text { Leafsheath } \\
\text { pigmentation }\end{array}$ & $0.21 *(0.08)$ & $0.27 * *(0.16)$ & $0.33 * *(0.13)$ & $0.14(0.43 * *)$ \\
\hline Plant vigour score & $0.35 * *$ & $0.33 * *$ & $0.37 * *$ & $0.23 *$ \\
\hline Leaf glossy score & $0.82 * *(0.59 * *)$ & $0.84 * *(0.75 * *)$ & $0.87 * *(0.76 * *)$ & $0.63 * *(0.69 * *)$ \\
\hline Leaf midrib colour & $-0.09(-0.01)$ & $-0.04(-0.15)$ & $0.02(-0.17)$ & $0.04(0.07)$ \\
\hline Waxy bloom & $0.48 * *$ & $0.53 * *$ & $0.54 * *$ & $0.30 * *$ \\
\hline Plant colour & $0.21 *$ & $0.24 *$ & $0.29 * *$ & 0.05 \\
\hline $\begin{array}{l}\text { Number of } \\
\text { trichomes } \\
\text { on the abaxial } \\
\text { surface }\end{array}$ & $-0.72 * *(-0.52 * *)$ & $-0.71 * *(-0.62 * *)$ & $-0.72 * *\left(-0.66^{* *}\right)$ & $-0.62 * *(-0.53 * *)$ \\
\hline $\begin{array}{l}\text { Number of } \\
\text { trichomes } \\
\text { on the adaxial } \\
\text { surface }\end{array}$ & $-0.72 * *(-0.59 * *)$ & $-0.70 * *(-0.61 * *)$ & $-0.72 * *(-0.68 * *)$ & $-0.63 * *(-0.57 * *)$ \\
\hline \multicolumn{5}{|l|}{ Seed/panicle traits } \\
\hline $\begin{array}{l}\text { Inflorescence } \\
\text { exsertion }\end{array}$ & $-0.05(-0.28 * *)$ & $-0.11\left(-0.25^{*}\right)$ & $-0.14(-0.27 * *)$ & $-0.15\left(-0.33^{* *}\right)$ \\
\hline $\begin{array}{l}\text { Inflorescence } \\
\text { compactness }\end{array}$ & $-0.36 * *(0.06)$ & $-0.38 * *(-0.13)$ & $-0.44 * *(-0.08)$ & $-0.30 * *(-0.22 *)$ \\
\hline Inflorescence shape & $-0.22 *\left(0.26^{* *}\right)$ & $-0.26 * *(0.10)$ & $-0.32 * *(0.18)$ & $-0.24 *(-0.02)$ \\
\hline Glume colour & $0.02(0.37 * *)$ & $0.01(0.28 * *)$ & $-0.04(0.34 * *)$ & $0.08(0.11)$ \\
\hline Glume coverage & $-0.14\left(-0.26^{* *}\right)$ & $-0.13(-0.27 * *)$ & $-0.17(-0.21 *)$ & $-0.08(-0.27 * *)$ \\
\hline Awns & $-0.35 * *(-0.36 * *)$ & $-0.42 * *(-0.27 * *)$ & $-0.38 * *(-0.14)$ & $-0.16(-0.44 * *)$ \\
\hline Grain colour & $0.37 * *(0.32 * *)$ & $0.34 * *(0.35 * *)$ & $0.35 * *(0.47 * *)$ & $0.30 * *(0.27 * *)$ \\
\hline Grain lustre & $-0.23 *(-0.15)$ & $-0.29 * *(-0.31 * *)$ & $-0.32 * *(-0.40 * *)$ & $-0.24 *(-0.20 *)$ \\
\hline Grain subcoat & $-0.05(0.10)$ & $-0.06(0.20 *)$ & $-0.05(0.25 *)$ & $-0.11(0.15)$ \\
\hline Endosperm texture & $0.40 * *(0.36 * *)$ & $0.31 * *(0.44 * *)$ & $0.33^{* *}\left(0.53^{* *}\right)$ & $0.47 * *(0.14)$ \\
\hline Endosperm colour & $0.34 * *(0.36 * *)$ & $0.37 * *(0.36 * *)$ & $0.39 * *(0.40 * *)$ & $0.36 * *(0.08)$ \\
\hline
\end{tabular}

The values outside the parenthesis are the correlation coefficients of rainy season, and those inside the parenthesis are for the postrainy season.

$*$,**Correlation coefficient significant at $\mathrm{P}=0.05$ and $\mathrm{P}=0.01$, respectively. 


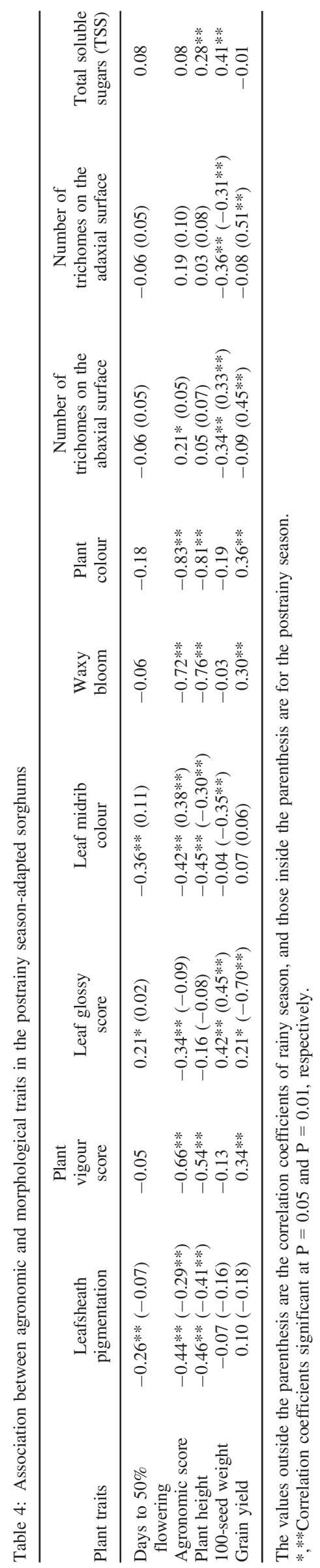


Table 5: Association between panicle and seed traits with agronomic traits in the postrainy season-adapted sorghums

\begin{tabular}{|c|c|c|c|c|c|}
\hline Plant traits & Days to $50 \%$ flowering & Agronomic score & Plant height & 100-seed weight & Grain yield \\
\hline Inflorescence exsertion & $-0.01(0.01)$ & $0.04(0.29 * *)$ & $-0.04(-0.15)$ & $-0.11(-0.08)$ & $-0.11(0.30 * *)$ \\
\hline Inflorescence compactness & $-0.12(0.29 * *)$ & $0.14(0.33 * *)$ & $0.01(0.03)$ & $-0.26^{* *}(0.15)$ & $-0.16(0.05)$ \\
\hline Inflorescence shape & $0.06(0.20 *)$ & $0.22 *(0.37 * *)$ & $0.13(0.15)$ & $-0.19(0.12)$ & $-0.17(-0.08)$ \\
\hline Glume colour & $0.23 *(-0.07)$ & $0.54 * *(0.32 * *)$ & $0.48 * *(0.15)$ & $0.24 *(0.38 * *)$ & $-0.34 * *(-0.37 * *)$ \\
\hline Glume coverage & $0.33 * *(0.03)$ & $0.50 * *(0.24 *)$ & $0.53 * *(0.35 * *)$ & $0.15(-0.19)$ & $-0.32 * *(0.23 *)$ \\
\hline Awns & $-0.02(0.24 *)$ & $0.46^{* *}\left(0.42^{* *}\right)$ & $0.51 * *(0.49 * *)$ & $0.15(0.07)$ & $-0.37 * *(0.35 * *)$ \\
\hline Grain colour & $0.35^{* *}(-0.07)$ & $0.23 *(0.17)$ & $0.23 *(0.29 * *)$ & $0.62 * *(0.20 *)$ & $-0.28 * *(-0.38 * *)$ \\
\hline Grain lustre & $-0.11(-0.02)$ & $0.06(-0.14)$ & $0.06(0.07)$ & $-0.12\left(-0.20^{*}\right)$ & $-0.02\left(0.33^{* *}\right)$ \\
\hline Grain subcoat & $-0.17(-0.09)$ & $-0.07(0.07)$ & $-0.01(-0.08)$ & $0.05(0.06)$ & $0.21 *(-0.23 *)$ \\
\hline Endosperm texture & $0.19(0.19)$ & $0.15(0.27 * *)$ & $0.32 * *(0.23 *)$ & $0.21 *(0.41 * *)$ & $-0.07\left(-0.35^{* *}\right)$ \\
\hline Endosperm colour & $0.36^{* *}(-0.17)$ & $0.16(0.18)$ & $0.26^{* *}(0.21 *)$ & $0.45 * *(0.11)$ & $-0.31 * *(-0.30 * *)$ \\
\hline
\end{tabular}

The values outside the parenthesis are the correlation coefficients of rainy season, and those inside the parenthesis are for the postrainy season. $*$,**Correlation coefficient significant at $\mathrm{P}=0.05$ and 0.01 , respectively.

yield exhibited a significant and positive correlation in the rainy season and a significant and negative correlation with shoot fly resistance in the postrainy season.

\section{Association of agronomic and morphological traits with resistance to shoot fly, Atherigona soccata}

Agronomic score and plant height were significantly and negatively correlated with leafsheath pigmentation, seedling vigour score, leaf midrib colour, waxy bloom and plant colour in both the seasons (Table 4). Agronomic score was positively associated with trichome density, while plant height was positively associated with TSS during the rainy season. The 100-seed weight was positively associated with leaf glossiness in both the seasons and with TSS in the rainy season, but negatively associated with trichome density in both the seasons and with leaf midrib colour during the postrainy season. Grain yield was positively associated with seedling vigour, leaf glossiness, waxy bloom and plant colour during the rainy season, and trichome density during the postrainy season contributes to high grain yield; however, leaf glossiness in the postrainy season and trichome density during the rainy season were negatively associated with grain yield.

Glume colour, glume coverage, presence of awns, grain colour, endosperm texture and endosperm colour were positively associated with agronomic score, plant height and 100-seed weight in both the seasons, whereas glume colour and endosperm colour showed a negative association with grain yield in both the seasons (Table 5). Grain coverage by the glumes and the presence of awns exhibited a positive association with grain yield in the postrainy season, but a negative association in the rainy season, suggesting that different combinations of traits contribute to high grain yield in the rainy and postrainy seasons.

Correlations between panicle traits with morphological traits indicated that inflorescence exsertion, glume coverage, presence of awns and grain lustre were positively associated with trichome density, but negatively with the leaf glossiness (Table 6). Grain colour, grain subcoat, endosperm texture and endosperm colour showed a positive association with leaf glossiness score, but a negative association with trichome density.

\section{Association of agronomic and morphological characteristics of sorghum}

Agronomic score was positively associated with days to $50 \%$ flowering, plant height and 100-seed weight, but negatively associated with grain yield in the rainy season (Table 7). Plant height showed a positive association with 100 -seed weight and days to $50 \%$ flowering, but a negative association with grain yield during the rainy season. The 100 -seed weight was negatively associated with grain yield in the postrainy season.

Overall resistance score, leafsheath pigmentation, seedling vigour score, leaf glossiness score, leaf midrib colour and waxy bloom were positively and significantly associated with each other in both the seasons (Table 8). Trichome density showed a negative association with overall resistance score, leafsheath pigmentation, seedling vigour score, leaf glossiness score and waxy bloom in both the seasons. Trichome density on the adaxial and abaxial surfaces of the leaf was significantly correlated in both the seasons $\left(r=0.99 * *\right.$ and $\left.0.96^{* *}\right)$.

Glume colour was positively associated with grain and endosperm colour in both the seasons; glume coverage and presence of awns in the rainy season; and endosperm texture in the postrainy season, but negatively associated with grain lustre in the postrainy season (Table 9). The grain covererage by the glumes was positively associated with awns in both the seasons and with grain colour, endosperm texture and endosperm colour in the rainy season. Grain colour was negatively associated with grain lustre in both the seasons and positively associated with endosperm texture and endosperm colour in both the seasons. Grain lustre was negatively associated with endosperm texture in the postrainy season and with endosperm colour in both the seasons, while endosperm texture was positively associated with endosperm colour in both the seasons.

\section{Grain yield potential of different sorghum genotypes during the rainy and postrainy seasons}

The mean performance of the genotypes for grain yield, and agronomic and panicle traits is given in Annexures S2, S3a and S3b. The genotype IS 2123 performed well in postrainy season and yielded $3.87 \mathrm{t} / \mathrm{ha}$, whereas CSV 15 yielded 7.10 t/ha during the rainy season. The genotypes ICSV 700, Phule Chitra, RHRB 12, RHRB 19, ICSV 707, ICSV 711, ICSV 714, ICSV 25022, ICSV 25026, ICSV 25027, IS 1044, IS 5604, IS 18662, Akola Kranti, ICSB 24002 and DJ 6514 yielded high across seasons, whereas ICSB 433, ICSB 463, Macia, ICSV 745, CSV 15, ICSV 713, ICSV 93089, IS 34726, IS 33844-5, Barsizoot, ICSB 52, ICSB 38, 296 B, ICSR 92003 and Swarna yielded high in the rainy season; Phule Yasodha, Phule Anuradha, Parbhani Moti, CSV 18R, ICSV 702, ICSV 25010, IS 1104, IS 2123, IS 2146, IS 2312, IS 5470, IS 5622 and ICSV 93046 exhibited high grain yield in the postrainy season. 


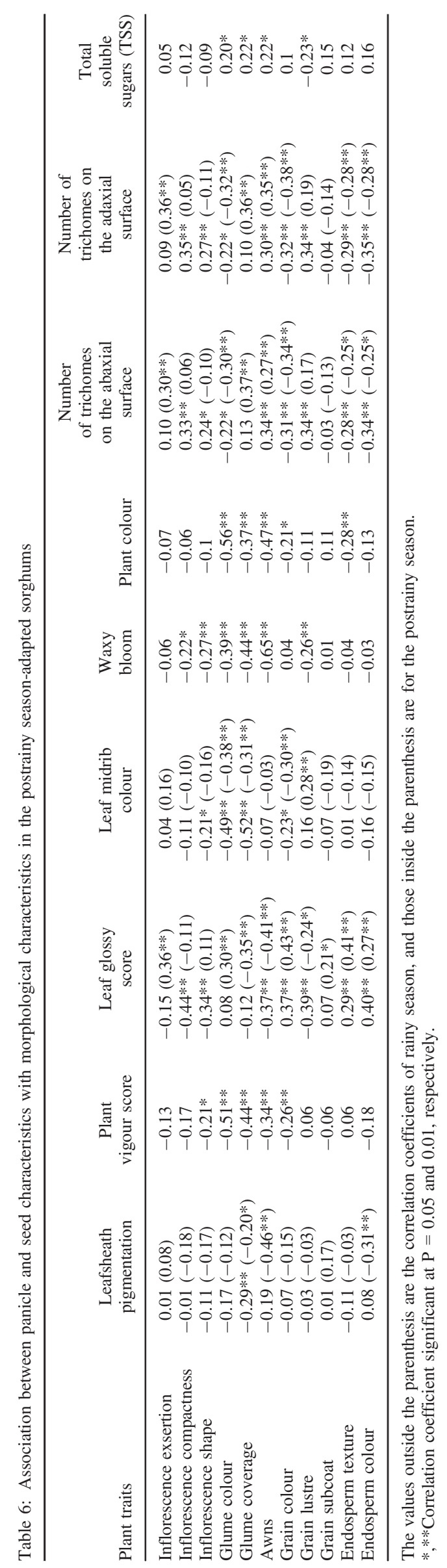


Table 7: Association between agronomic characteristics in the postrainy season-adapted sorghums

\begin{tabular}{lcccr}
\hline Plant traits & Days to 50\% flowering & Agronomic score & Plant height & 100-seed weight \\
\hline Agronomic score & $0.27^{* *}(0.03)$ & 1 & & \\
Plant height & $0.35^{* *}(0.13)$ & $0.76^{* *}\left(0.50^{* *}\right)$ & 1 & \\
100-seed weight & $0.20^{*}(0.15)$ & $0.14\left(0.41^{* *}\right)$ & $0.30^{* *}\left(0.31^{* *}\right)$ & 1 \\
Grain yield & $0.20^{*}(-0.14)$ & $-0.54^{* *}(0.04)$ & $-0.27^{* *}(0.14)$ & $-0.04\left(-0.49^{* *}\right)$ \\
\hline
\end{tabular}

The values outside the parenthesis are the correlation coefficients of rainy season, and those inside the parenthesis are for the postrainy season.

$*, * *$ Correlation coefficient significant at $\mathrm{P}=0.05$ and 0.01 , respectively.

Table 8: Association between the morphological characteristics in the postrainy season-adapted sorghums

\begin{tabular}{|c|c|c|c|c|c|c|c|c|}
\hline Plant traits & ORS & $\begin{array}{c}\text { Leafsheath } \\
\text { pigmentation }\end{array}$ & $\begin{array}{l}\text { Plant } \\
\text { vigour } \\
\text { score }\end{array}$ & $\begin{array}{l}\text { Leaf glossy } \\
\text { score }\end{array}$ & $\begin{array}{l}\text { Leaf } \\
\text { midrib } \\
\text { colour }\end{array}$ & $\begin{array}{l}\text { Waxy } \\
\text { bloom }\end{array}$ & $\begin{array}{l}\text { Plant } \\
\text { colour }\end{array}$ & $\begin{array}{l}\text { Number of } \\
\text { trichomes on } \\
\text { the abaxial } \\
\text { surface }\end{array}$ \\
\hline $\begin{array}{l}\text { Leafsheath } \\
\text { pigmentation }\end{array}$ & $0.14\left(0.43^{* *}\right)$ & 1.00 & & & & & & \\
\hline Plant vigour score & $0.23 *$ & $0.46 * *$ & 1.00 & & & & & \\
\hline Leaf glossy score & $0.63 * *(0.69 * *)$ & $0.32 * *(0.29 * *)$ & $0.31 * *$ & 1.00 & & & & \\
\hline Leaf midrib colour & $0.04(0.07)$ & $0.35 * *(0.21 *)$ & $0.36^{* * *}$ & $-0.02(-0.15)$ & 1.00 & & & \\
\hline Waxy bloom & $0.30 * *$ & $0.50 * *$ & $0.60 * *$ & $0.52 * *$ & $0.31 * *$ & 1.00 & & \\
\hline Plant colour & 0.05 & $0.53 * *$ & $0.70 * *$ & $0.33 * *$ & $0.45^{* *}$ & $0.76^{* *}$ & 1.00 & \\
\hline $\begin{array}{l}\text { Number of trichomes } \\
\text { on the abaxial } \\
\text { surface }\end{array}$ & $-0.62 * *(-0.53 * *)$ & $-0.18\left(-0.26^{* *}\right)$ & -0.17 & $-0.73 * *(0.72 * *)$ & $0.11(0.13)$ & $-0.30 * *$ & -0.05 & 1.00 \\
\hline $\begin{array}{l}\text { Number of trichomes } \\
\text { on the adaxial } \\
\text { surface }\end{array}$ & $-0.63 * *(-0.57 * *)$ & $-0.19\left(-0.26^{* *}\right)$ & -0.15 & $-0.73 * *(0.77 * *)$ & $0.13(0.16)$ & $-0.27 * *$ & -0.02 & $0.99 * *(0.96 * *)$ \\
\hline
\end{tabular}

The values outside the parenthesis are the correlation coefficients of rainy season, and those inside the parenthesis are for the postrainy season. $*$,**Correlation coefficient significant at $\mathrm{P}=0.05$ and 0.01 , respectively.

Based on the relationship between grain yield of the test genotypes across seasons (Fig. 2), the genotypes ICSV 25026, ICSV 707 and ICSB 24002 (quadrant IV) exhibited high grain yield in both the seasons. The genotypes CSV 15, RHRB 12, Macia, 296B, ICSR 92006, ICSV 745, Swarna, ICSB 433, IS 34726 and ICSV 714 (quadrant II) performed well in the rainy season, while IS 2123, IS 5622, IS 2312, IS 5470, IS 2146, ICSV 25027, CSV 18R and IS 5604 (quadrant III) exhibited high grain yield potential in the postrainy season.

\section{Direct and indirect effects of morphological traits on grain yield}

Path coefficient analysis for grain yield as a dependent factor during the postrainy season revealed that trichomes on adaxial surface of the leaf exhibited positive and significant correlation with grain yield $\left(r=0.55^{* *}\right)$ and had the maximum direct effects (0.46), with positive indirect effects through leaf glossiness score (0.37) and negative indirect effect through trichomes on the abaxial surface of the leaf $(-0.52)$ (Table 10). Similarly, trichomes on the abaxial surface of leaves showed negative direct effects $(-0.54)$, but the indirect effects were positive through leaf glossiness score (0.35), and trichomes on adaxial leaf surface $(0.45)$, but had a significant and positive correlation with grain yield $\left(r=0.48^{* *}\right)$. Leaf glossiness score showed negative direct effects $(-0.47)$ on grain yield, and its indirect effects through other traits were also negative, except the trichomes on the abaxial leaf surface $(0.40)$. Leaf glossiness showed a negative and significant correlation with grain yield $(-0.72 * *)$.

Maximum direct effects $(0.53)$ were shown by the trichomes on the adaxial leaf surface, with a significant and positive correlation with grain yield in the rainy season $\left(r=0.21^{*}\right)$. The 100 -seed weight showed positive direct effect $(0.41)$ and was significantly correlated with grain yield $\left(r=0.56^{* *}\right)$ (Table 11). The parameters with correlation and path coefficients in the same direction could be used to select for shoot fly resistance in the postrainy season.

Stepwise regression analysis indicated that factors contributing to grain yield and shoot fly resistance differ in both the seasons. Leaf glossiness score, 100-seed weight (test weight) and plant height explained $56.31 \%$ of the variation for grain yield [grain yield $(Y)=2.66+0.01$ plant height $\left(X_{1}\right)-0.31$ test weight $\left(X_{2}\right)$ - 0.35 leaf glossiness score $\left(X_{3}\right)$ ], whereas plants with shoot fly eggs and trichomes on the adaxial leaf surface explained $75.55 \%$ of the total variation in deadhearts during the postrainy season [shoot fly deadhearts $(Y)=20.51+0.69$ percentage of plants with shoot fly eggs $\left(X_{1}\right)-0.11$ trichomes on adaxial surface $\left(X_{2}\right)$ ]. During the rainy season, none of the factors accounted for a significant variation in grain yield, but the number of shoot fly eggs per 100 plants, plants with shoot fly eggs and leaf glossiness score explained $92.03 \%$ of the variation for percentage of plants with shoot fly deadhearts [Shoot fly deadhearts $(Y)=0.44+10.09$ total number of shoot fly eggs per 100 plants $\left(X_{1}\right)+0.56$ percentage of plants with shoot fly eggs $\left(X_{2}\right)+5.34$ leaf glossiness score $\left(X_{3}\right)$ ].

\section{Discussion}

Shoot fly resistance is a highly complex character with low heritability and high environmental influence for shoot fly damage (Aruna et al. 2011). The experimental results indicated that the genotypic response differs across seasons. Oviposition non-pref- 


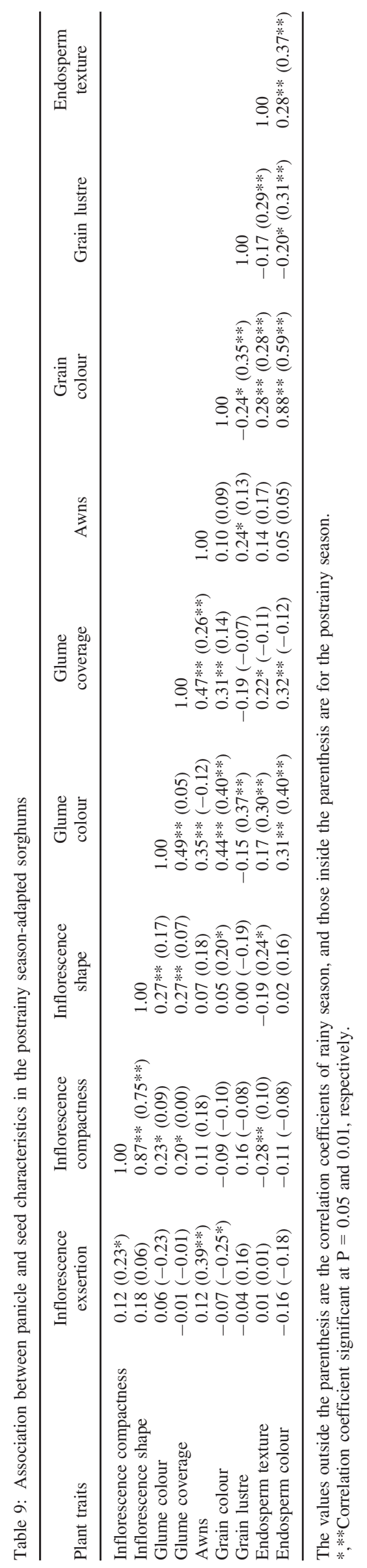




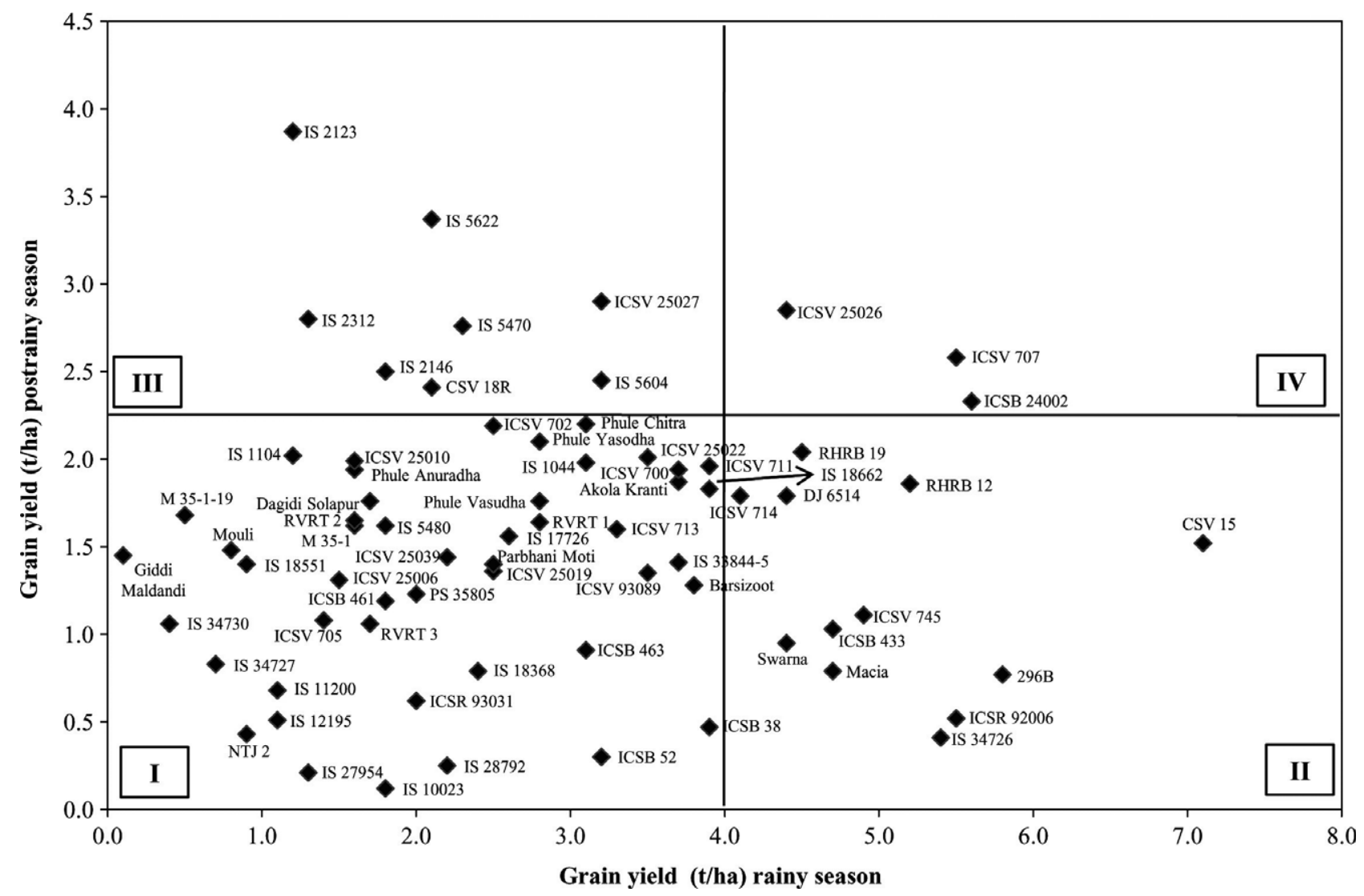

Fig. 2: Relationship between the grain yield in rainy and postrainy seasons and response of the genotypes across the seasons

Table 10: Direct and indirect effects of shoot fly resistance, morphological and seed/panicle characteristics on grain yield during the postrainy season

\begin{tabular}{|c|c|c|c|c|c|c|c|c|c|c|c|c|}
\hline Plant traits & $\begin{array}{c}\text { Number } \\
\text { of shoot } \\
\text { fly } \\
\text { eggs/100 } \\
\text { plants }\end{array}$ & $\begin{array}{l}\text { Plants } \\
\text { with } \\
\text { shoot } \\
\text { fly } \\
\text { eggs } \\
(\%)\end{array}$ & $\begin{array}{c}\text { Plants } \\
\text { with } \\
\text { shoot fly } \\
\text { deadhearts } \\
(\%)\end{array}$ & $\begin{array}{l}\text { Leaf } \\
\text { glossy } \\
\text { score }\end{array}$ & $\begin{array}{l}\text { Number } \\
\text { of } \\
\text { trichomes } \\
\text { on the } \\
\text { abaxial } \\
\text { surface }\end{array}$ & $\begin{array}{l}\text { Number } \\
\text { of } \\
\text { trichomes } \\
\text { on the } \\
\text { adaxial } \\
\text { surface }\end{array}$ & $\begin{array}{c}100- \\
\text { seed } \\
\text { weight }\end{array}$ & $\begin{array}{l}\text { Inflorescence } \\
\text { exsertion }\end{array}$ & $\begin{array}{l}\text { Glume } \\
\text { colour }\end{array}$ & $\begin{array}{l}\text { Glume } \\
\text { coverage }\end{array}$ & Awns & $\begin{array}{l}\text { Grain } \\
\text { yield }\end{array}$ \\
\hline $\begin{array}{l}\text { Number of shoot } \\
\text { fly eggs } / 100 \text { plants }\end{array}$ & 0.11 & -0.10 & -0.02 & -0.27 & 0.28 & -0.27 & -0.05 & -0.01 & -0.04 & 0.00 & -0.05 & $-0.40^{* *}$ \\
\hline $\begin{array}{l}\text { Plants with shoot } \\
\text { fly eggs }(\%)\end{array}$ & 0.05 & -0.19 & -0.03 & -0.35 & 0.35 & -0.30 & -0.11 & -0.00 & -0.03 & 0.00 & -0.03 & $-0.64 * *$ \\
\hline $\begin{array}{l}\text { Plants with shoot } \\
\text { fly deadhearts }(\%)\end{array}$ & 0.06 & -0.16 & -0.04 & -0.36 & 0.37 & -0.33 & -0.09 & -0.01 & -0.04 & 0.00 & -0.02 & $-0.61^{* * *}$ \\
\hline Leaf glossy score & 0.06 & -0.14 & -0.03 & -0.47 & 0.40 & -0.36 & -0.09 & -0.01 & -0.04 & 0.00 & -0.05 & $-0.72 * *$ \\
\hline $\begin{array}{l}\text { Number of } \\
\text { trichomes on } \\
\text { the abaxial surface }\end{array}$ & -0.05 & 0.12 & 0.02 & 0.35 & -0.54 & 0.45 & 0.07 & 0.01 & 0.04 & -0.00 & 0.03 & $0.48 * *$ \\
\hline $\begin{array}{l}\text { Number of } \\
\text { trichomes on } \\
\text { the adaxial surface }\end{array}$ & -0.06 & 0.12 & 0.03 & 0.37 & -0.52 & 0.46 & 0.07 & 0.01 & 0.04 & -0.00 & 0.04 & $0.55^{* *}$ \\
\hline 100-seed weight & 0.02 & -0.10 & -0.02 & -0.21 & 0.19 & -0.16 & -0.20 & -0.00 & -0.04 & 0.00 & 0.01 & $-0.51 * *$ \\
\hline $\begin{array}{l}\text { Inflorescence } \\
\text { exsertion }\end{array}$ & -0.03 & 0.05 & 0.01 & 0.17 & -0.16 & 0.17 & 0.02 & 0.01 & 0.03 & 0.00 & 0.05 & $0.30 * *$ \\
\hline Glume colour & 0.04 & -0.05 & -0.01 & -0.14 & 0.17 & -0.16 & -0.07 & -0.01 & -0.12 & 0.00 & -0.02 & $-0.36^{* *}$ \\
\hline Glume coverage & -0.03 & 0.04 & 0.01 & 0.15 & -0.19 & 0.15 & 0.03 & 0.00 & -0.00 & -0.01 & 0.04 & 0.20 \\
\hline Awns & -0.04 & 0.05 & 0.01 & 0.19 & -0.15 & 0.16 & -0.01 & 0.01 & 0.02 & -0.00 & 0.12 & $0.34 * *$ \\
\hline
\end{tabular}

${ }^{1}$ Correlation coefficient significant at $\mathrm{P}=0.01$; highlighted diagonal values are direct effects; Residual effect $=0.62$.

erence (antixenosis), antibiosis and tolerance are the major components of resistance in sorghum to shoot fly (Doggett et al. 1970, Raina et al. 1981, Sharma and Nwanze 1997, Dhillon et al. 2005, 2006a, Sivakumar et al. 2008). Leaf surface chemicals influence the host plant resistance by the A. soccata females (Chamarthi et al. 2011), while trichomes hinder the movement of shoot fly maggot to reach the growing point (Sharma and Nwanze 1997). In the present studies, several genotypes 
Table 11: Direct and indirect effects of shoot fly resistance, morphological and seed/panicle characteristics on grain yield during the rainy season

\begin{tabular}{|c|c|c|c|c|c|c|c|c|c|c|}
\hline Plant traits & $\begin{array}{l}\text { Plant } \\
\text { vigour } \\
\text { score }\end{array}$ & $\begin{array}{c}\text { Leaf } \\
\text { glossy } \\
\text { score }\end{array}$ & $\begin{array}{l}\text { Waxy } \\
\text { bloom }\end{array}$ & $\begin{array}{l}\text { Plant } \\
\text { colour }\end{array}$ & $\begin{array}{c}\text { Number of } \\
\text { trichomes } \\
\text { on the } \\
\text { abaxial } \\
\text { surface }\end{array}$ & $\begin{array}{c}\text { Number of } \\
\text { trichomes } \\
\text { on the } \\
\text { adaxial } \\
\text { surface }\end{array}$ & $\begin{array}{c}\text { Days to } \\
50 \% \\
\text { flowering }\end{array}$ & $\begin{array}{l}\text { Plant } \\
\text { height }\end{array}$ & $\begin{array}{c}100- \\
\text { seed } \\
\text { weight }\end{array}$ & Grain yield \\
\hline Plant vigour score & 0.16 & 0.00 & -0.03 & 0.06 & 0.02 & -0.03 & 0.03 & -0.02 & 0.02 & $0.30 * *$ \\
\hline Leaf glossy score & 0.03 & 0.00 & -0.03 & 0.01 & 0.31 & -0.42 & -0.15 & 0.00 & -0.11 & -0.18 \\
\hline Waxy bloom & 0.08 & 0.00 & -0.05 & 0.06 & 0.13 & -0.15 & -0.02 & -0.02 & -0.03 & 0.17 \\
\hline Plant colour & 0.10 & 0.00 & -0.03 & 0.10 & -0.05 & 0.09 & 0.10 & -0.03 & 0.04 & $0.39 * *$ \\
\hline $\begin{array}{l}\text { Number of trichomes } \\
\text { on the abaxial surface }\end{array}$ & -0.01 & -0.00 & 0.02 & 0.01 & -0.40 & 0.52 & 0.11 & -0.01 & 0.08 & 0.19 \\
\hline $\begin{array}{l}\text { Number of trichomes on } \\
\text { the adaxial surface }\end{array}$ & -0.01 & -0.00 & 0.02 & 0.02 & -0.39 & 0.53 & 0.12 & -0.01 & 0.09 & $0.21 *$ \\
\hline Days to $50 \%$ flowering & -0.01 & 0.00 & -0.01 & -0.03 & 0.14 & -0.19 & -0.32 & 0.02 & -0.23 & $-0.55^{* *}$ \\
\hline Plant height & -0.08 & 0.00 & 0.03 & -0.07 & 0.03 & -0.05 & -0.14 & 0.04 & -0.07 & $-0.40 * *$ \\
\hline 100-seed weight & 0.01 & 0.00 & 0.01 & 0.01 & -0.08 & 0.11 & 0.18 & -0.01 & 0.41 & $0.56 * *$ \\
\hline
\end{tabular}

$*$,**Correlation coefficient significant at $\mathrm{P}=0.05$ and 0.01 respectively; highlighted diagonal values are direct effects; Residual effect $=0.70$.

exhibited non-preference for oviposition, of which some also showed antibiosis component of resistance against the survival of shoot fly larvae. Oviposition by sorghum shoot fly is significantly and negatively associated with trichome density and leaf glossiness (Omori et al. 1983, Dhillon et al. 2005). Similar associations were confirmed in the present studies. Genotypes with glossy and trichomed leaves are resistant to shoot fly damage, which are inherited independently, and apparently have an additive effect in reducing shoot fly damage (Maiti and Gibson 1983, Maiti et al. 1984, Sharma and Nwanze 1997, Dhillon et al. 2005, 2006a,b). Light pink-pigmented plants with low chlorophyll content are less susceptible to shoot fly damage (Singh et al. 1981, Kamatar et al. 2003, Dhillon 2004, Dhillon et al. 2005, 2006c, Chamarthi et al. 2011). In the present study, the leaf glossiness, leafsheath pigmentation, seedling vigour and trichomes on the abaxial and adaxial surface were found to be positively associated with shoot fly resistance as reported earlier (Taneja and Leuschner 1985) However, vigour was earlier reported to be associated negatively with shoot fly resistance (Dhillon et al. 2005, Chamarthi et al. 2011). Shoot fly-resistant lines have faster seedling growth, shorter peduncle and longer stems and internodes (Sharma and Nwanze 1997). Recovery or overall resistance is a type of plant response to shoot fly damage, in which the plants have the ability to recover from shoot fly damage through the production of secondary tillers with productive panicles once the main plant is damaged by shoot fly. Recovery resistance was highly associated with the level of primary resistance and shoot fly density (Blum 1969, Doggett et al. 1970, Jotwani and Srivastava 1970, Raina 1985, Sharma and Nwanze 1997). The shoot fly-resistant genotypes produce more numbers of uniform productive tillers than the susceptible ones and, at times, yield more under shoot fly infestation (Sharma and Nwanze 1997). The overall resistance score was positively associated with 100 -seed weight, leafsheath pigmentation, seedling vigour score, leaf glossiness score, waxy bloom, grain colour, endosperm texture and endosperm colour, suggesting that the genotypes with a combination of these traits can be selected for resistance to $A$. soccata.

The seasonal variation in the expression of resistance to shoot fly damage is influenced by the effect of climatic factors on the survival and development of shoot fly, and the indirect effects through plant growth and biochemical composition of the host plants (Sharma 2014). High $\mathrm{G} \times \mathrm{E}$ interactions for deadheart percentage has been reported earlier by Singh and Rana (1986) and Aruna et al. (2011). Therefore, there is a need to adopt different strategies to breed for shoot fly resistance during the rainy and the postrainy seasons, for example grain yield was positively correlated with shoot fly-resistant traits such as number of shoot fly eggs per 100 plants, percentage of plants with shoot fly eggs, plants with deadhearts and overall resistance score during the rainy season, but negatively correlated during the postrainy season. Some of the sorghum genotypes exhibit an inherent ability to produce side tillers after the main shoot is killed by shoot fly. These genotypes can produce reasonable grain yields if the plant is not attacked again (Taneja and Leuschner 1985). Although the shoot fly infestation was high during the rainy season, the genotypes recovered from the damage and produced productive tillers because of the availability of moisture, resulting in higher grain yield (Ashok Kumar et al. 2008). However, during the postrainy season, the grain yield was negatively correlated with shoot fly resistance traits as the grain yield was influenced by shoot fly damage, and there was limited capacity to recover from shoot fly damage as shoot fly population is high during the postrainy season and the tillers generated were also infested by shoot fly.

Grain yield is influenced by many biotic and abiotic factors and the physicochemical traits of the plant. Correlation coefficients provide information on dependence/association among the traits. However, it is difficult to pinpoint the major factors that affect the expression of resistance/grain yield because of the intricate interactions between the traits being examined. Therefore, path coefficient analysis and stepwise regression were used to understand the nature of such interactions. Path coefficients serve as an effective parameter for determining the relative contribution/effect of individual traits, to identify the traits which have direct effects and correlation coefficients (+ve or $-v e)$ in the same direction for use in crop improvement (Sharma et al. 1990).

The present studies suggested that leaf glossiness, trichomes, leafsheath pigmentation and seedling vigour can be used as morphological markers to select for shoot fly resistance in sorghum, and the genotypes showing resistance to shoot fly damage can be used in the sorghum improvement programmes for developing cultivars with shoot fly resistance and adaptation to the postrainy season.

Development of shoot fly-resistant parents is critical for producing shoot fly-resistant hybrids (Jayanthi et al. 1996, Reddy Belum et al. 1997). The grain yield was negatively associated with plant vigour and leaf glossiness and positively associated 
with trichome density in the postrainy season, but the trichome density was negatively associated in the rainy season. As a result of such intricate interactions, it is difficult to combine traits conferring resistance to shoot fly damage with high grain yield. The genotypes Phule Chitra, ICSV 707, ICSV 711, IS 5604 and Akola Kranti exhibited moderate levels of resistance to shoot fly with high grain yield, and hence, these genotypes can be involved in breeding the shoot fly-resistant sorghums with adaptation to the postrainy season. Among them, Phule Chitra and Akola Kranti are the released cultivars for postrainy season cultivation and are being disseminated to farmers on-large scale. ICSB 463, ICSB 713 and ICSV 93089 showed resistance to shoot fly in the rainy season and had high grain yield, whereas ICSV 25010, IS 2146 and IS 2312 exhibited resistance to A. soccata with high grain yield potential in the postrainy season, suggesting that there is a need to follow season-specific strategies to breed for developing cultivars with high grain yield and resistance to shoot fly.

\section{Acknowledgements}

We thank the sorghum entomology staff for their support in carrying out the field experiments, and Bill \& Melinda Gates Foundation for financial support through HOPE-Sorghum and Millets project. We also thank Dr. P. Srinivas Rao for his valuable suggestions on the manuscript and Dr. Anand Kanatti for his help in statistical analysis.

\section{References}

Aruna, C., V. R. Bhagwat, V. Sharma, T. Hussain, R. B. Ghorade, G. Khandalkar, S. Audilakshmi, and N. Seetharama, 2011: Genotype $\times$ Environment interactions for shoot fly resistance in sorghum [Sorghum bicolor (L.) Moench]: response of recombinant inbred lines. Crop Prot. 30, 623-630.

Ashok Kumar, A., Belum V. S. Reddy, H. C. Sharma, and B. Ramaiah, 2008: Shoot fly (Atherigona soccata) resistance in improved grain sorghum hybrids. SAT eJ., 6, $1-4$.

Belum, V. S. Reddy, H. C. Sharma, R. P. Thakur, S. Ramesh, F. Rattunde, and M. Mgonja, 2006: Sorghum Hybrid Parents Research at ICRISAT-Strategies, Status, and Impacts. International Crops Research Institute for the Semi-Arid Tropics (ICRISAT), Patancheru, Andhra Pradesh, India.

Blum, A., 1969: Factors associated with tiller survival in sorghum varieties resistant to the sorghum shoot fly (Atherigona varia soccata). Crop Sci. 9, 388-391.

Borad, P. K., and V. P. Mittal, 1983: Assessment of losses caused by pest complex to sorghum hybrid, CSH 5. In: B. H. Krishnamurthy Rao, and K. S. R. K. Murthy (eds), Crop Losses due to Insect Pests, Special Issue of Indian Journal of Entomology, 271278. Entomological Society of India, Hyderabad, Andhra Pradesh, India.

Chamarthi, S. K., H. C. Sharma, K. L. Sahrawat, L. M. Narasu, and M. K. Dhillon, 2011: Physico-chemical mechanisms of resistance to shoot fly, Atherigona soccata in sorghum, Sorghum bicolor. J. Appl. Entomol. 135, 446-455.

CAC (Codex Alimentarius Commission), 2011: Discussion paper on mycotoxins in Sorghum. Joint FAO/WHO Food Standards Programme CODEX Committee on contaminants in foods' 5th Session held in The Hague, The Netherlands on 21 - 25 March.

Dhillon, M. K., 2004: Effects of cytoplasmic male-sterility on expression of resistance to sorghum shoot fly, Atherigona soccata (Rondani). PhD Thesis, Department of Entomology, Chaudhary Charan Singh Haryana Agricultural University, Hisar, Haryana, India.

Dhillon, M. K., H. C. Sharma, R. Singh, and J. S. Naresh, 2005: Mechanisms of resistance to shoot fly, Atherigona soccata in sorghum. Euphytica 144, 301-312.
Dhillon, M. K., H. C. Sharma, B. V. S. Reddy, R. Singh, and J. S. Naresh, 2006a: Inheritance of resistance to sorghum shoot fly, Atherigona soccata. Crop Sci. 46, 1377-1383.

Dhillon, M. K., H. C. Sharma, J. S. Naresh, R. Singh, and G. Pampapathy, 2006b: Influence of cytoplasmic male sterility on expression of different mechanisms of resistance in sorghum to Atherigona soccata (Diptera: Muscidae). J. Econ. Entomol. 99, 1452-1461.

Dhillon, M. K., H. C. Sharma, R. Singh, and J. S. Naresh, 2006c: Influence of cytoplasmic male-sterility on expression of physico-chemical traits associated with resistance to sorghum shoot fly, Atherigona soccata (Rondani). SABRAO J. Breed. Genet. 38, 105-122.

Doggett, H., K. J. Starks, and S. A. Eberhart, 1970: Breeding for resistance to the sorghum shoot fly. Crop Sci. 10, 528-531.

FAO, 2014: Crops primary equivalent. Available at: www.faostat.fao.org (last accessed October 25, 2014).

GenStat, 2010: Introduction to GenStat for Windows Genstat, 13th edn. VSN International, Hemel Hempstead, UK.

GENRES, 1994: Data entry module for genres statistical software pascal intl software solution. Version, 3. p. 11.

IBPGR and ICRISAT, 1993: Descriptors for Sorghum [Sorghum bicolor (L.) Moench]. International Board for Plant Genetic Resources, Rome, Italy; International Crops Research Institute for the Semi-Arid Tropics, Patancheru, Andhra Pradesh, India.

ICRISAT (International Crops Research Institute for the Semi-Arid Tropics), 1992: The Medium Term Plan, Volume 2. International Crops Research Institute for the Semi-Arid Tropics (ICRISAT), Patancheru, Andhra Pradesh, India.

ICRISAT (International Crops Research Institute for the Semi-Arid Tropics), 2007: The Productivity and Livelihoods of Success in the SAT Nourished, Archival Report. International Crops Research Institute for the Semi-Arid Tropics (ICRISAT), Patancheru, Andhra Pradesh, India.

Jayanthi, P. D. K., B. V. S. Reddy, D. D. R. Reddy, T. B. Gour, and K. F. Nwanze, 1996: Genetics of shoot fly resistance in sorghum hybrids of cytoplasmic male sterile lines. Page 152 in Abstracts of poster sessions: 2nd International Crop Science Congress: Crop Productivity and Sustainability - Shaping the Future, 17-24 Nov. 1996, National Academy of Agricultural Sciences and Indian Council of Agricultural Research, New Delhi, India.

Jotwani, M. G., and K. P. Srivastava, 1970: Studies on sorghum lines resistant against shoot fly, Atherigonavaria soccata Rond. Indian J. Entomol. 32, 1-3.

Jotwani, M. G., 1978: Investigations on Insect Pests of Sorghum and Millets with Special Reference to Host Plant Resistance. Final Technical Report (1972-1977), Research Bulletin of the Division of Entomology, Indian Agricultural Research Institute, New Delhi, India.

Kamatar, M. Y., P. M. Salimath, R. L. R. Kumar, and T. S. Rao, 2003: Heterosis for biochemical traits governing resistance to shoot fly in sorghum [Sorghum bicolor (L.) Moench]. Indian J. Genet. 63, 124127.

Maiti, R. K., and F. R. Bidinger, 1979: Simple approaches to the identification of shoot fly tolerance in sorghum. Indian J. Plant Prot. 7, 135 -140 .

Maiti, R. K., and R. W. Gibson, 1983: Trichomes in segregating generations of sorghum matings, II. Associations with shoot fly resistance. Crop Sci. 23, 76-79.

Maiti, R. K., K. E. Prasada Rao, P. S. Raju, and L. R. House, 1984: The glossy trait in sorghum: its characteristics and significance in crop improvement. Field Crops Res. 9, 279-289.

Omori, T., B. L. Agrawal, and L. R. House, 1983: Componential analysis of the factors influencing shoot fly resistance in sorghum [Sorghum bicolor (L.) Moench]. Jpn. Agric. Res. Q. 17, 215-218.

Raina, A. K., H. Z. Thindwa, S. M. Othieno, and R. T. Corkhill, 1981: Resistance in sorghum to sorghum shoot fly: larval development and adult longevity and fecundity on selected cultivars. Int. J. Trop. Insect Sci. 2, 99-103.

Raina, A. K., 1985: Mechanisms of resistance to shoot fly in sorghum: a review. In: V. Kumble (ed.), Proceedings, International Sorghum Entomology Workshop, 15-21 July 1984, Texas A \& M University, College Station, Texas, USA, 131-136. International Crops Research 
Institute for the Semi-Arid Tropics (ICRISAT), Patancheru, Andhra Pradesh, India.

Reddy Belum, V. S., H. F. W. Rattunde, and J. W. Stenhouse, 1997: Breeding sorghums for insect resistance. In: H. C. Sharma, Faujdar Singh, and K. F. Nwanze (eds), Plant Resistance to Insects in Sorghum, 115-126. International Crops Research Institute for the Semi-Arid Tropics (ICRISAT), Patancheru, Andhra Pradesh, India.

SAS Institute Inc., 2004: SAS/STAT 9.2 User's Guide. SAS Institute Inc., Cary, NC.

Sharma, H. C., 1985: Future strategies for pest control in sorghum in India. Trop. Pest Manag. 31, 167-185.

Sharma, H. C., P. Vidyasagar, and K. Leuschner, 1990: Components of resistance to the sorghum midge, Contarinia sorghicola Coq. Ann. Appl. Biol. 116, 327-333.

Sharma, H. C., S. L. Taneja, K. Leuschner, and K. F. Nwanze, 1992: Techniques to Screen Sorghums for Resistance to Insect Pests. Information Bulletin no. 32. International crops research institute for the Semi-Arid tropics (ICRISAT), Patancheru, Andhra Pradesh, India.

Sharma, H. C., 1993: Host-Plant Resistance to insects in sorghum and its role in integrated pest management. Crop Prot. 12, 11-34.

Sharma, H. C. and K. F. Nwanze, 1997: Mechanisms of Resistance to Insects and Their Usefulness in Sorghum Improvement. Information Bulletin no. 55, International Crops Research Institute for the SemiArid Tropics (ICRISAT), Patancheru, Andhra Pradesh, India.

Sharma, H. C., S. L. Taneja, N. Kameswara Rao, and K. E. Prasada Rao, 2003: Evaluation of Sorghum Germplasm for Resistance to Insect Pests. Information Bulletin no. 63, International Crops Research Institute for the Semi-Arid Tropics (ICRISAT), Patancheru, Andhra Pradesh, India.

Sharma, H. C., B. V. S. Reddy, M. K. Dhillon, K. Venkateswaran, B. U. Singh, G. Pampapathy, R. Folkerstma, C. T. Hash, and K. K. Sharma, 2005: Host plant resistance to insects in Sorghum: present status and need for future research. Int. Sorghum Millets Newsl. 46, 36 - 43.

Sharma, H. C., 2014: Climate change effects on insects: implications for crop protection and food security. J. Crop Improv. 29, 229-259.
Singh, B. U., B. S. Rana, and N. G. P. Rao, 1981: Host plant resistance to mite (Oligonychus Indicus H.) and its relationship with shoot fly (Atherigona soccata Rond.) resistance in sorghum. J. Entomol. Res. 5, $25-30$.

Singh, B. U., and B. S. Rana, 1986: Resistance in sorghum to the shoot fly, Atherigona soccata Rondani. Int. J. Trop. Insect Sci. 7, 577-587.

Sivakumar, C., H. C. Sharma, M. Lakshmi Narasu, and G. Pampapathy, 2008: Mechanisms and diversity of resistance to shoot fly, Atherigona soccata in Sorghum bicolor. Indian J. Plant Prot. 36, 249-256.

Soto, P. E., 1974: Ovipositional preference and antibiosis in relation to resistance to sorghum shoot fly. J. Econ. Entomol. 67, 265-267.

Taneja, S. L., and K. Leuschner, 1985: Resistance screening and mechanisms of resistance in sorghum to shoot fly. In: Proceedings of the International Sorghum Entomology Workshop, 15-21 July, 1984, Texas A and M University, College Station, Texas, USA, 115-129. International Crops Research Institute for the Semi-Arid Tropics (ICRISAT), Patancheru, Andhra Pradesh, India.

\section{Supporting Information}

Additional Supporting Information may be found in the online version of this article:

Annexure S1. Morphological characteristics of sorghum genotypes evaluated for resistance to sorghum shoot fly, Atherigona soccata (ICRISAT, Patancheru, 2010-2011).

Annexure S2. Agronomic characteristics of sorghum genotypes evaluated for resistance to sorghum shoot fly, Atherigona soccata (ICRISAT, Patancheru, 2010-2011).

Annexure S3a. Panicle and grain characteristics of sorghum genotypes evaluated for resistance to sorghum shoot fly, Atherigona soccata during the rainy season (ICRISAT, Patancheru, 2010-2011).

Annexure S3b. Panicle and grain characteristics of sorghum genotypes evaluated for resistance to sorghum shoot fly, Atherigona soccata during the postrainy season (ICRISAT, Patancheru, 2010-2011). 